\title{
To Study about Effect of Sulphur on Growth and Development on Mustard (Brassica juncia L. Czern and Coss.) Varieties
}

\author{
Mukesh Kumar ${ }^{1}$, Anil Nishad ${ }^{2}$, Hemant Kumar Sinha ${ }^{3}$ and Raghuraj Yadav ${ }^{1}$ \\ ${ }^{1}$ Department of Agronomy, ANDUA \&T Kumarganj, Ayodhya (Uttar Pradesh), India \\ ${ }^{2}$ KVK, Singrauli (Madhya Pradesh), India \\ ${ }^{3}$ KVK, Chhattarpur (Madhya Pradesh), India \\ *Corresponding author
}

\begin{abstract}
A B S T R A C T
Keywords

Mustard, Plant

height, Leaf area index, Dry matter, Number of branches per plant

Article Info

Accepted:

26 July 2020

Available Online:

10 August 2020

A field experiment was conducted during the rabi seasons of 2016-17 to assess the effect of sulphur levels on yield and quality of mustard (Brassica juncea L.). The experiment was conducted with randomized block design and replicated three times. Twelve treatment combinations consisted of four sulphur levels viz., 0, 15, 30 and $45 \mathrm{~kg} \mathrm{~S}$ ha-1 and three varieties viz., NDR-8501, Varuna and Maya were allocated randomly. Results revealed that all the growth, yield attributes and quality were increased significantly under $45 \mathrm{~kg} \mathrm{~S}$ ha-1. The growth characters viz., plant height $(\mathrm{cm})$, leaf area index, dry matter accumulation and number of branches plant-1 and yield attributes like number of siliqua plant-1, number of seed siliquqa-1, length of siliqua $(\mathrm{cm})$ and seed and stover yields of mustard crop were significantly higher with Narendra Rai-8501 as compared to Varuna and Maya.
\end{abstract}

\section{Introduction}

According to area and production both, mustard stands in second place among oil seed crops of India. Mustard is grown in tropical sub-tropical areas of the world. 33.8 $\%$ (7.49 million hectare) area of the total cultivated area of world is in India. $16 \%$ of world total production is produced by India. Maximum yield of mustard $(8.40 \mathrm{q} / \mathrm{ha})$ is recorded in Jammu and Kashmir (source: DACNET). The name 'mustard, is derived from the Latin word mustum, or must of old wine mixed with crushed seed makes it one of the most important spice inthe world (Hemingway 1976). In India, rape seed mustard is an important source of edible oil followed by ground nut (pandy er a/ 1999). They are cultivated in 4.83 million ha in a wide range of agro- ecological conditions, resulted in the production of 5.34 million tones of Rapeseed mustard in $2001-2002$ and our productivity is $1106 \mathrm{~kg} / \mathrm{ha}$ (Anonymous, 2002). In the recent past, the area under brown mustard is on the increase at the cost of other Brassicas due to its higher productivity and tolerance to biotic and abiotic stresses. The major area is covered by Indian Mustard. 
Rapeseed cultivation is confined only to northern India because of late maturitv and shattering of pots owing to high temperature prevailing during harvest in Februarv March(Dutt and Chopra 20O1). The information regarding optimum dose of sulphur and its influence on mustard is necessary to augement the productivity and quality of Indian mustard. Sulphur level significantly influenced the seed and stover yield of mustard (Sharma et al., 2008).

\section{Materials and Methods}

The experiment was carried out during rabi season 2016-17at the Agronomy Research Farm of the Narendra Deva University of Agriculture and Technology, Kumarganj, Faizabad (U.P.) on the topic "To study about effect of sulphur on growth and development on mustard (Brassica juncia L. Czern and Coss.) varieties." The research farm is situated at a distance of about $45 \mathrm{~km}$ in southeast from Faizabad on Faizabad - Raibareli road. Geographically, experimental site falls under the sub-tropical zone and located at $26.470 \mathrm{~N}$ latitude, $82.120 \mathrm{E}$ longitude and an altitude of 113 meters above mean sea level and is subjected to extremes of weather conditions. The experiment was conducted with randomized block design and replicated three times. Twelve treatment combinations consisted of four sulphur levels viz., 0, 15, 30 and $45 \mathrm{~kg} \mathrm{~S}$ ha-1 and three varieties viz., NDR-8501, Varuna and Maya were allocated randomly. The different growth parameters studied were mustard as.

\section{Results and Discussion}

Plant height increase successively with increasing sulphur level up to $45 \mathrm{~kg} \mathrm{~S}$ ha-1 significantly. Higher plant height was recorded under $45 \mathrm{~kg}$ sulphur which was at par at $30 \mathrm{~kg} \mathrm{~S}$ ha-1 and significantly superior over control and $15 \mathrm{~kg} \mathrm{~S}$ ha-1 at all this crop growth stages, except 30 DAS (Table 1). Leaf area index sowing a rapid increase between 30 to 60 DAS has presented in Table no. 2 highest values recorded at 60 DAS. Thereafter, declined trends were noticed in all varieties. Active growth lies between 30 and 60 DAS.

Table.1 Plant height of mustard as influenced by sulphur levels and varieties

\begin{tabular}{|l|c|c|c|c|}
\hline \multirow{2}{*}{ Treatments } & \multicolumn{4}{|c|}{ Plant height (cm) } \\
\cline { 2 - 5 } & 30 DAS & 60 DAS & 90 DAS & At harvest \\
\hline Sulphur levels $\left(\mathbf{k g ~ h a}^{-\mathbf{1}}\right)$ \\
\hline $\mathbf{0}$ & 21.63 & 64.39 & 123.80 & 150.21 \\
\hline $\mathbf{1 5}$ & 21.85 & 65.76 & 126.28 & 153.10 \\
\hline $\mathbf{3 0}$ & 22.30 & 69.19 & 132.47 & 160.31 \\
\hline $\mathbf{4 5}$ & 22.97 & 71.93 & 137.43 & 166.08 \\
\hline SEm \pm & 0.483 & 1.304 & 2.749 & 3.911 \\
\hline CD $(\mathbf{P}=\mathbf{0 . 0 5})$ & NS & 3.778 & 7.962 & 11.331 \\
\hline Varieties & & & & \\
\hline NDR -8501 & 22.70 & 75.35 & 142.29 & 170.62 \\
\hline Varuna & 22.21 & 67.86 & 128.73 & 154.84 \\
\hline Maya & 21.66 & 60.24 & 118.96 & 146.81 \\
\hline SEm \pm & 0.418 & 1.130 & 2.380 & 3.387 \\
\hline CD $(\mathbf{P}=\mathbf{0 . 0 5})$ & NS & 3.272 & 6.896 & 9.813 \\
\hline
\end{tabular}


Table.2 Leaf area index of mustard as influenced by sulphur levels and varieties

\begin{tabular}{|l|c|c|c|}
\hline \multirow{2}{*}{ Treatments } & \multicolumn{3}{|c|}{ Leaf area index } \\
\cline { 2 - 4 } & 30 DAS & 60 DAS & 90 DAS \\
\hline Sulphur levels (kg ha-1) & & \\
\hline 0 & 1.60 & 3.87 & 2.93 \\
\hline $\mathbf{1 5}$ & 1.62 & 4.17 & 3.15 \\
\hline $\mathbf{3 0}$ & 1.65 & 4.39 & 3.32 \\
\hline $\mathbf{4 5}$ & 1.70 & 4.56 & 3.45 \\
\hline S.Em. $\mathbf{E}$ & 0.038 & 0.112 & 0.070 \\
\hline C.D. $(\mathbf{p = 0 . 0 5 )}$ & $\mathrm{NS}$ & 0.112 & 0.202 \\
\hline Varieties & & & 3.58 \\
\hline NDR -8501 & 1.68 & 4.74 & 3.21 \\
\hline Varuna & 1.64 & 4.24 & 2.84 \\
\hline Maya & 1.60 & 3.76 & 0.060 \\
\hline S.Em. \pm & 0.033 & 0.097 & 0.175 \\
\hline C.D. $(\mathbf{p = 0 . 0 5 )}$ & 0.096 & 0.282 & \\
\hline
\end{tabular}

Table.3 Number of branches plant-1 of mustard as influenced by sulphur levels and varieties

\begin{tabular}{|l|c|c|c|c|}
\hline \multirow{2}{*}{ Treatments } & \multicolumn{4}{|c|}{ Number of branches plant-1 } \\
\cline { 2 - 5 } & 30 DAS & 60 DAS & 90 DAS & At \\
\hline Sulphur levels (kg ha-1) & 14.85 & 18.72 & 18.35 \\
\hline O & 2.04 & 16.01 & 20.18 & 19.77 \\
\hline $\mathbf{1 5}$ & 2.06 & 16.83 & 21.22 & 20.79 \\
\hline $\mathbf{3 0}$ & 2.10 & 17.49 & 22.05 & 21.61 \\
\hline $\mathbf{4 5}$ & 2.16 & 0.393 & 0.475 & 0.447 \\
\hline S.Em. \pm & 0.047 & 1.139 & 1.375 & 1.295 \\
\hline C.D. $(\mathbf{p = 0 . 0 5 )}$ & 0.135 & & & \\
\hline Varieties & & 18.10 & 22.82 & 22.37 \\
\hline NDR -8501 & 2.13 & 16.30 & 20.55 & 20.14 \\
\hline Varuna & 2.09 & 14.47 & 18.25 & 17.88 \\
\hline Maya & 2.04 & 0.340 & 0.411 & 0.387 \\
\hline S.Em. \pm & 0.040 & 0.986 & 1.191 & 1.122 \\
\hline C.D. $(\mathbf{p}=\mathbf{0 . 0 5 )}$ & 0.117 & & & \\
\hline
\end{tabular}


Table.4 Dry matter accumulation as influenced by sulphur levels and varieties

\begin{tabular}{|l|c|c|c|c|}
\hline \multirow{2}{*}{ Treatments } & \multicolumn{4}{|c|}{ Dry matter accumulation (g plant-1) } \\
\cline { 2 - 5 } & 30 DAS & 60 DAS & 90 DAS & At harvest \\
\hline Sulphur levels (kg ha-1) & & & \\
\hline 0 & 1.70 & 13.59 & 30.33 & 35.15 \\
\hline $\mathbf{1 5}$ & 1.72 & 14.65 & 32.69 & 37.88 \\
\hline $\mathbf{3 0}$ & 1.75 & 15.40 & 34.37 & 39.83 \\
\hline $\mathbf{4 5}$ & 1.80 & 16.01 & 35.72 & 41.39 \\
\hline S.Em. $\mathbf{\pm}$ & 0.035 & 0.349 & 0.704 & 0.871 \\
\hline C.D. $(\mathbf{p = 0 . 0 5 )}$ & 0.035 & 1.010 & 2.039 & 2.522 \\
\hline Varieties & & & & \\
\hline NDR -8501 & 1.78 & 16.57 & 36.98 & 42.85 \\
\hline Varuna & 1.75 & 14.92 & 33.29 & 38.58 \\
\hline Maya & 1.70 & 13.25 & 29.56 & 34.26 \\
\hline S.Em. $\mathbf{\pm}$ & 0.031 & 0.302 & 0.609 & 0.754 \\
\hline C.D. $(\mathbf{p = 0 . 0 5 )}$ & 0.088 & 0.875 & 0.609 & 2.184 \\
\hline
\end{tabular}

Leaf area index increased with increase in dose of sulphur up to $45 \mathrm{~kg} \mathrm{~S}$ ha-1 at 30,60 and 90 DAS of mustard crop. $45 \mathrm{~kg} \mathrm{~S}$ ha-1 significantly increase leaf area index at all growth stages, except at 30 DAS. Data pertaining to number of branches plant-1 of mustard as affected by sulphur levels and varieties recorded at successive growth stages have been presented in Table no. 3. Number of branches plant-1 increased with increasing sulphur levels. Highest number of branches plant-1 was recorded with at $45 \mathrm{~kg} \mathrm{~S}$ ha-1 which was at par at $30 \mathrm{~kg} \mathrm{~S}$ ha-1 and significantly higher over control and $15 \mathrm{~kg} \mathrm{~S}$ ha-at all the stages of crop growth, except at 30 DAS. Maximum number of branches plant-1 was recorded by NDR-8501 which was significantly higher over Varuna and Maya at all the growth stages of crop growth, except at 30 DAS. Dry matter accumulation plant-1 increased significantly with increase in dose of sulphur up to $45 \mathrm{~kg} \mathrm{~S}$ ha-1 at 30 , 60,90 DAS and harvest stage of mustard crop, which was par at $30 \mathrm{~kg} \mathrm{~S}$ ha-1 and significantly superior over control and $15 \mathrm{~kg}$ $\mathrm{S}$ ha-1 at all growth stages of crop growth, except 30 DAS (Table 4). The interaction effect between different levels of sulphur and varieties on dry matter accumulation plant-1 was found non-significant at all the stages of crop growth. Among the varieties NDR-8501 recorded significantly higher dry matter accumulation at 60,90 DAS and at harvest as compared to Varuna and Maya, respectively.

In conclusion different levels of sulphur application significantly influenced plant height at 60, 90 DAS and at harvest. Application of $45 \mathrm{~kg} \mathrm{~S}$ ha-1 resulted in significantly higher plant height at 60, 90 DAS and harvest (71.93, 137.43 and 166.08 $\mathrm{cm}$ respectively) but it was statistically at par with $30 \mathrm{~kg} \mathrm{~S}$ ha-1 and significantly superior over control and $15 \mathrm{~kg} \mathrm{~S}$ ha-1. Application of $45 \mathrm{~kg} \mathrm{~S}$ ha-1 produced significantly higher number of branches plant- 1 but statistically at par with $30 \mathrm{~kg} \mathrm{~S}$ ha-1 and significantly superior over control and $15 \mathrm{~kg} \mathrm{~S}$ ha-1. The leaf area index significantly increased with the variety NDR-8501 at all the growth stages of crop, except 30 DAS over the remaining varieties (Varuna and Maya). The maximum dry matter accumulation plant-1 was recorded with variety NDR-8501 which was 
significantly higher than Varuna and Maya at all growth stages, except 30 DAS. The maximum branches plant-1 was recorded by variety NDR-8501 which was significantly higher over Varuna and Maya, at all growth stages, except 30 DAS.

\section{References}

Sharma, R., Dahiya, S.S., Yadav, H.D. and Singh, M.(2008). Effect of sulphur application on yield attributes, yield, S uptake and oil content of Indian mustard (Brassica juncea L.). Haryana Agricultural University, Journal of Research, 35 (2): 135-138.
Anonymous 2002. Agriculture statistics at a glance, Government of India, New Delhi, pp 100-101.

Panday. I.D, Basudeo Singh and J.N. Sachan 1999. Brassica Hybrid research in India: status and prospects. Proceedings of the tenth international rape seed congress. Canberra, Australia.

Hemingway, J.S. 1976. Mustards in Evolution of Crop plants, Ed. N.W. Summonds Longman, London of New York.

Dutt B. K. and N. K. Chopra 2O01. Improved technology in mustard threshing Indian Farming: 7:14-15 Hemingway, J.S. 1976.

\section{How to cite this article:}

Mukesh Kumar, Anil Nishad, Hemant Kumar Sinha and Raghuraj Yadav. 2020. To Study about Effect of Sulphur on Growth and Development on Mustard (Brassica juncia L. Czern and Coss.) Varieties. Int.J.Curr.Microbiol.App.Sci. 9(08): 3666-3670.

doi: https://doi.org/10.20546/ijcmas.2020.908.423 